\title{
PONDOK, TSANGAYA, AND OLD AGE SPIRITUAL WELLBEING
}

\author{
Received: 18-01-2021
}

Revised: 16-03-2021

Accepted: 25-07-2021

\begin{abstract}
Abu Bakar Yakubu
Department of Sociology Faculty of Humanities, Management and Social Sciences Federal University Kashere, PMB 0182 Gombe Stater

Email:yakubua7@gmail.com
\end{abstract}

\begin{tabular}{ll}
\hline Keywords: & Abstract \\
Islamic Religious & A Comparative analysis of practices obtained between the Pondok and \\
Education (IRE), & Tsangaya with regard to traditional Islamic education and \\
Religous & spirituality in Malaysia and Nigeria, indicates that, despite areas of \\
Character, & similarity in origin and evolution, there exist a unique area of sharp \\
Curricullum & contrast in relation to later life spirituality and elder care. The article \\
Developtment, & maintains that, despite the two systems sharing wider similarities of \\
originating from the traditional system of Arabic and Islamic \\
education, the Pondok provides a complete platform for the spiritual \\
life cycle, with opportunities for devotion from childhood to death. \\
The Tsangaya on the other hand, covers childhood to early adulthood, \\
thus, presenting a halfway approach to the spiritual life cycle. \\
Recommendations were based on the need for the Tsangaya to model \\
along aspects of the Pondok in a manner that will enable the \\
incorporation of later life spiritual needs of the elderly. The purpose of \\
this article is to carry out a comparative analysis of these two systems \\
of traditional Islamic education, in relation to eldercare and spiritual \\
wellbeing. The relevance of this paper lies in the fact that population \\
aging is currently receiving attention as global crises, and issues of \\
elderly wellbeing in all aspects are being explored towards addressing \\
the needs of the elderly
\end{tabular}

\section{INTRODUCTION}

Islamic religious madrasas or schools permeate all over the Muslim world. In Indonesia, Malaysia and Thailand these are referred to as the "Pesantren" or "Pondoks", while the rough equivalent that exist in Africa especially in most parts of Northern Nigeria, Niger, Cameroun, chad and Mali , are known as "Tsangaya" or "makarantar Allo". This article will discuss the Pondoks and Tsangaya in relation to spiritual wellbeing in old age.

Historical details indicated common features in the evolution of the Islamic traditional educational systems of Pondok and Tsangaya, particularly in Malaysia and 
Nigeria. This is based on the common origin of both from the "Kuttab" or "madrasah" in the Arab world, North Africa, and parts of Asia. The Pondok in Malaysia, the "Pesantren" in Indonesia, and Tsangaya or "al-Majiri" in Nigeria, both refer to traditional methods of teaching Islam across these different cultures (Hashim R. 2011). As such, both share a common historical background concerning Islam and the contents of teachings. However, there exist major differences in the approach towards accommodating the individual in later life

\section{CLARICICATION OF CONCEPTS}

Pondoks: In Malaysian communities, Pondoks provides the basic forum for a complete life cycle of religious education, and spiritual needs at different stages of an individual's life span, through old age

Tsangaya: a system of teaching Quran and Islamic education, based on the 'Timbuktu tradition' of scholarship/education throughout the West-African subregion. It refers to a traditional method of acquiring and memorizing the Glorious Qur'an, among Hausa/Fulani where boys at their tender ages are sent out by their parents or guardians to other villages, towns or cities, for Qur'an education under a knowledgeable Islamic scholar called "Malam"(muallim). The system offers spiritual preparation up to maturity from Almajiri to Gardi. The younger 'alamjiri' (student) can reside in Tsangaya, while upon graduation he moves out of the Tsangaya. For adults, there is no choice of going back to the Tsangaya as "Gardi" to spend the remaining days of their lives. Daily consultation remains the main method of contact with the Tsangaya resulting in distractions from devotions.

Old age: old age or senescence stage, refers to final stage in an organism's normal life span. In humans, there exist no single position on the age at which a person becomes old. As such the "elderly" are regarded as those 60 years and over. Further classifications are; the young old from the age of 60 to 74, the aged, from the age of 75 and above, the oldest old, from the age of 80 , and the oldest old, from the age of 85 and over. It is the stage in which there is high tendency of spirituality and devotion among the elderly as they prepare transition trough death. Among the Malaysians, one can choose to go back to the Pondok to spend the remaining days of their lives.

Spirituality In this work, spirituality is broadly conceived as a system of deeper connection with a Allah. The emphasis is on devotion and Spirituality as a need in old 
age that is necessary for preparing the inevitable transition to "Akhira", also referred to as later life. In Islam it involves various forms of activities that require an environment in which there is less worldly distractions.

\section{Overview of the evolution of Pondoks}

For generations, the Pondok as a social institution has contributed to developments of the intellectual circles within Malay community. The Pondok has remain Malaysia's earliest way traditional Islamic religious learning. As an institution, the contributions made by Pondok towards the development of Islamic religious spirituality in Malaysia is so enormous and extends to most parts of Southeast Asia in general. Pondoks have survived over the years despite numerous challenges associated with social change and globalization ${ }^{1}$. Therefore, historically, it can be said that, the spiritual life of the elderly Malaysians is linked to the Pondok

History: In Malaysia, , the history of the Pondok system began in Pasai when Sultan Malik al-Zahir was in power in 14th century (1345-1346,). It was introduced to Acheh during reign of Sultan Iskandar Thani (1636-1641) in the 16th -17th century and spread into Patani. When Acheh collapsed, the spread advanced into Patahi and Trengganu at the same period, from the late part of 18th century into 19th and 20th centuries. Earlier, Kelantan had been exposed to religious education since the 16th century but the establishment of Pondoks took place in the 19th century (F. Noor 2007, Buang 2007)(Yusoff et al., 2017). The Pondok system has therefore, played an early role in the religious and spiritual life of Malaysians.

As noted by Rosnani ${ }^{2}$., Pondok "Tok Pulai Chondong" was the pioneer Pondok in Kelantan area established around 1820. The establishment of the Pondoks in addition to the early exposure of region to Islamic education, has made the Kelantan system of education distinctively significant in the history of Islamic education in Malaysia. Most Pondoks in the region are concentrated across the plains, however, the

${ }^{1}$ Zurita Mohd Yusoff dkk., "Contemporary Fiqh Thoughts of Shaykh Abdul Malik bin Abdullah (1650-1736AD) in Kitab al-Kifayah," International Journal of Academic Research in Business and Social Sciences 7, no. 4 (2017): 2222-6990, https://doi.org/10.6007/IJARBSS/v7i4/2774; MZHBZ Abidin, PB Maidin, dan MYBY Salleh, "Survival of the Pondok Learning Institution in Malaysia," International Journal of, 2017; M Samuel, MY Tee, dan LP Symaco, "The Educational Landscape of Malaysia," Education in Malaysia, 2017.

${ }^{2}$ Yusoff dkk., "Contemporary Fiqh Thoughts of Shaykh Abdul Malik bin Abdullah (16501736AD) in Kitab al-Kifayah." 
largest and most significant is situated in the foothills of the hinterland (ulu) there is also another location on plain closer to the Thai border (Winzeler 1975, Rosnani 2004).

The main purpose of the Pondok as core institution in Malay world for centuries, is the center where most of the indigenous Malaysian elite obtain their training. In the history of Kelantan, Trengganu and Patani, the Pondoks were responsible for the production of a generation of Muslim scholars that actually contributed to the Malay world of letters. (F. Noor n.d., F. Noor 2007, Rosnani 2004). .

\section{Overview of the evolution of Tsangaya}

Prior to the establishment of the Tsangaya system, the African system of traditional education prevailed all over African societies. It was generally a system that is indigenous and in which functionalism was the guiding principles. The traditional system merely serves the purpose of induction into society and preparation for adulthood. Generally, it emphasizes on social responsibility, job orientation, political participation and spiritual responsibility and moral values. The method of learning was participatory, and children learn by participation through rituals, initiation ceremonies, recitations and demonstrations. secret cults serve as higher institutions. According to Fafunwa, ${ }^{3}$ the cardinal principles upon which the goals of education in African societies are based includes among others: 1) To develop the child's latent physical kills. 2) To develop character, 3) To inculcate respect for elders and those in position of authority. 4) To develop intellectual skills. 5) To acquire specific vocational training and to develop a healthy attitude toward honest labor. 6) To develop sense of belonging and to participate actively in family and community affairs. 7) To understand appreciate and promote the cultural heritage of the community at large

Early Traditional African educational system was highly spiritual in pagan practices. However, eventually, the Tsangaya system started in the 11th century as a result of the involvement of Borno rulers in Qur'anic literacy. Over seven hundred years later, the Sokoto Caliphate was founded principally through an Islamic revolution based on the teachings of the Holy Qur'an. Within these two Islamic empires, similar Qur'anic learning system existed and eventually came to be known as the Tsangaya or Almajiri system. ${ }^{4}$

${ }^{3}$ A. Babs Fafunwa, History of Education in Nigeria, 2004 ed. (ibadan: defemson, 2004).

4 AbdulQadir I. A., "“The Al-Majiri System of Education in Nigeria Today.," "www.gamji.com/index.php/SJPAS/article/view/637, 2015. 
Before colonial rule in Nigeria, the Tsangaya pupils were taught as they lived with their parents in Tsangaya schools located within the immediate local environment of the pupil. However, with advent of the Caliphate of Sheik Usman bin Fodio, some innovations were made. An inspectorate of Qur'anic learning administration was established and inspectors reported directly to the Emir of the province, concerning all matters relating to the school. Therefore, the responsibility of maintaining the Tsangaya schools was borne by the Caliphate and respective Emirates, Communities, parents, proceeds of 'Zakkah' profit accruing from 'Waqf'.

The main reason behind the development of these schools follows the spread of Islam especially in "Bilad Sudan" into "Hausa land". The "Wangarawa" traders and scholars were noted as the sole promoters of Islamic education based on the Maliki school. Between 13th - 18th centuries and through rise and fall of different empires in the Bilad as Sudan such as Ghana, Mali and Songhai and Bornu empires. Islamic scholarship and spirituality was well established with capability of producing great scholars, saints and excellent centers of learning. Such spirituality and scholarship also served as a movement in the revival attempt towards salvation and salvage of societies from social evils across the Bilad as Sudan. (Sulaiman I. 1986, Van Beek 1988), the Tsangaya like the Pondoks formed the basis for Islamic education and spirituality in Hausa land.

Consequently, many cities came to prominence as centers of learning and spirituality for example "Gao", "Djenne" and "Timbuktu" in the former 'Songhai' Empire and "Kano", "Katsina" and "Zaria" in Hausa land. Like Kelantan in Malaysia, Timbuktu was the most important city of learning, scholarship and piety in devotion across the lifespan of an individual. The Mosque in "Sankore" attracts thousands of scholars and students from all parts of the 'Bilad - as - Sudan'. In most literature Sankore Mosque is considered a University by many scholars of West African history. Teaching from Timbuktu spread and dominated the whole of Bilad as Sudan. The result is the establishment of an educational tradition of teaching and learning known as the 'Timbuktu tradition' with high spirituality and devotion to "Auliya" throughout the West-African sub-region. This formed the foundation of the Tsangaya traditional schools that have survived in Northern Nigeria today. Another factor responsible for

${ }^{5}$ AbdulQadir I. A. 
the spread 'Timbuktu tradition', known as the Tsangaya in many northern Nigerian towns, cities and rural areas. was mainly due to the establishment of the caliphate that transformed the socio-economic and political structures in Hausa land, paving the way for the spread of literacy and Islamic knowledge and the flow of Islamic literature ${ }^{6}$. As such, similar to the Pondoks there was lifelong scholarship and spirituality in later life as a matter of choice in the Tsangaya system devotion.

A turning point in the history of the Tsangaya was the advent of British rule. This development saw the invasion of the northern region and the killing and deposition of Emirs. Consequently, most Emirs became less powerful and lost control of their territories. They were as well forced to accept new roles, as mere traditional rulers. Colonial rule therefore led to the initial loss of control of the Tsangaya system. Furthermore, abolishment of emirate funding of the Tsangaya system due to the promotion of secular administration in government further retarded the growth of Tsangaya system. As a result the system collapsed and remain what is obtained today. 7. Tsangaya now with its attendant failure in inculcating both Qur'anic education and morality and has remained a victim of Western education that was alternatively introduced and aggressively funded. The Tsangaya pupils now were transformed into beggars or Almajirai together with their 'Mallams. So along with this failure also diminished the type and forum for spiritual devotion provided by the Tsangaya over the life span.

\section{Potentiality of Tsangaya and Pondok in Spiritual devotion}

Despite various Reforms and intervention efforts at local and national levels, official and unofficial communal circles. revival of the Tsangaya remains frustrated. Among the factors responsible are the rise of Islamiyah Schools between 1956 and 2000 as Alternatives of Tsangaya which has led to a shift in emphasis from strict Tsangaya. The most recent research in Kano conducted by the office of the Special Adviser on Education and Information Technology reveals that there are up to 14, 335 Tsangaya Schools in Kano as one out of 36 States with a student population of 1,272,844, and 45,

${ }^{6}$ Ibraheem A.K., "The Jihad and the Consolidation of Sudanic Intellectual Tradition," dalam International Conference on the Bicentenary of the Sokoto Caliphate 1804-2004, 2004, online version; Van Beek, "Intensive slave raiding in the colonial interstice: Hamman Yaji and the Mandara Mountains (North Cameroon and North-eastern Nigeria)No Title," The Journal of African History 53, no. 03 (2012): 301-23.

7 AbdulQadir I. A., "“The Al-Majiri System of Education in Nigeria Today." 
454 teachers. Yet research findings have shown that there are no well-organized systems of reviving Tsangaya in place within Northern Nigeria ${ }^{8}$.

In contrasts, the Pondoks still thrive and are ever expanding. In order to ensure the survival of the Pondoks, efforts are made to preserve the Pondoks in championing the cause of Islamic education in communities across Malaysia. Various agencies, bodies and associations over the years have been put in place to protect the continued existence of the Pondoks. This effort covered welfare and overall development of the pondoks. Among these examples are : Pusat Pembangunan Pondok Berhad, Yayasan Pembangunan Pondok Malaysia (YPPM), Agama Kedah (HESA), and (PPPB) Pertubuhan Hal Ehwal Sekolah?.

Furthermore, the central government in Malaysia realized fully the relevance of the Pondok institution and the great contribution it has made over the years in the overall social process. Consequently, a Non-profit organization was founded known as the "Yayasan Pembangunan Pondok Malaysia (PPM) in recognition to Pondoks who have contributed towards the development of Islamic religious education in Malaysia. Also recognizes is the valuable contributions made by the "ulama's" and teachers of Pondok. More still, to develop Pondok institutions resources have been committed in the budget to ensure annually that, administration, welfare, physical structures finance, and other basic needs are provided ${ }^{10}$. Both Tsangaya and the Pondok may have potential but the Pondoks are more promising as centers of spirituality in old age.

\section{Nature of Pondok and Tsangaya Systems in Malaysia and Nigeria}

The Pondok in the Malay world, refers to the traditional Islamic schools where provisions are made for a religious boarding of male students, who reside in the Pondok and study under the sole direction of a guru referred to as "tuan guru"11. The residential nature of the Pondok educational system is confirmed by Rosnani, (2004) who describes it as such an institution consisting of a centrally located building, in which is found the teacher's house or a mosque, fenced by rackets of small huts or abodes. an educational institution, Pondok are sources of Islamic religious teaching

8 Salisu Shehu, "No TiIMPROVING QUR'ANIC (TSANGAYA) EDUCATION IN NIGERIA Trends, Issues, Challenges and the Way Forward tle," dalam Tsangaya System of Education, Organized by the Borno State Agency for Mass Education, Maiduguri, 2006, na.

${ }^{9}$ Abidin, Maidin, dan Salleh, "Survival of the Pondok Learning Institution in Malaysia."

${ }^{10}$ Abidin, Maidin, dan Salleh.

11 A Rahim dkk., "Talaqqi Method in Teaching and Learning Islamic Education at Pondok Institutions," 2016. 
and scholarship in which residential facilities are provided especially for younger Muslim students coming from diverse background ${ }^{1213}$. The Pondoks are therefore conducive environments for devotion in later life as needed by elderly people.

Among the Pondoks variations exists in the nature of the physical environment, organization, syllables, procedures of instruction, target audience and name given to the Pondok. ${ }^{1415}$

According to Buang, (2007), the small huts constituting the Pondok are normally built by students in order for them to live around their guru's residence and pray in his "Surau" (prayer house). The aim is to keep close proximity with one's guru. Since the Pondok is built as a place of residence, the students can stay for as long as it takes to pursue religious studies with a 'guru irrespective of age (Buang 2007). In time, this living facility is extended later to the elderly for religious learning opportunity and to spend their later life there. It is considered a unique living arrangement in Malaysia that caters for the elderly similar to other elderly institutions in terms of their congregated characteristic; however it is not age segregated and has different purposes for its establishment ${ }^{16}$. This provides a rare opportunity for life long devotion. As result of the stable nature of the Pondok, the elderly Malay elderly persons have a choice to move into a Pondok or to be fully engaged in learning and spiritual activity in later life.

The Al-Majiri System is rooted in the Islamic tradition of giving priority to the acquisition of knowledge over worldly materialism by the Muslim believers. It was a highly spiritual system predominantly made up of the Qadiriyya and Tijjaniya adherents. The word al-Majiri, derives from an Arabic term al-Muhajir referring to a traveler or migrant (Fafunwa 1974). In Northern Nigeria, the concept refers to schoolage children seeking knowledge by leaving their homes and parental comfort to nearby towns and cities to join a Tsangaya. This is line with lessons obtained from various

${ }_{12}$ MM Mydin dan NS Ahmad, "The system of Islamic studies at madrasah (sekolah pondok)," 2014.

${ }^{13}$ H.S. Awang, "Current Program Implementation and Evaluation.," dalam Proceedings of the National Seminar on Challenges of Senior Citizens Towards Vision 2020, 1992; A Abdullah, "The Influence of Ethnic Values on Managerial Practices in Malaysia," Malaysian Management Review, 1993, 3-18.

14 NA Areff dan N Lyndon, "Meanings of old age to the elderly in pondok living arrangement in Malaysia," Mediterranean Journal of Social Sciences, 2015.

${ }^{15}$ Awang, "Current Program Implementation and Evaluation."

${ }^{16}$ Areff dan Lyndon, "Meanings of old age to the elderly in pondok living arrangement in Malaysia." 
expeditions for knowledge of famous Islamic scholars such as al-Imam as-Shafie (767CE-820CE) and Ibn Khaldun (1332CE-1406CE). (Fafunwa 1974, Gbadamosi 1978)

Similar to Pondoks, the Tsangaya refers a home or a setting in a village, town or city under a "Mallam" (Mu-allim ) where he resides with the students known as "Almajirai" or "Gardawa" . A Tsangaya student refers to a boy or young man in search of knowledge in distant places from his home. The travel to far distance in pursuit of education is allied to the Prophet Mohammed's Hijra (migration) from Mecca to Medina (Yusha'u M. 2013). In contrast to the Pondok, Tsangaya does not expand due to the number of older students but only to accommodate more younger ones. In addition, the elderly are not accommodated to reside as obtained in the Pondok. unlike Pondoks which are highly accommodative of the elderly in contrast the Tsangaya does not contain them as residents.

The individual method of teaching was used in the Qur'anic schools. The Tsangaya system allows the students to read at his own capacity. The teacher teaches the pupil specific portion of the Qur'an on a wooden slate, the child goes to recite the portion until he has mastered it. He goes back to the teacher and recites the portion to the hearing of his teacher, when the teacher is satisfied of the recital he then adds more to the ones earlier learned by the student. This process continues until the student finishes the whole Qur'an at his pace ${ }^{17}$. Next comes the memorization stage. Initially the student chooses or selects a memorization stage of a grouping of chapters of the Qur'an that fall within his intelligence and memorization capacity. The student takes his slate for recitation with other experts in attendance, correction is made on orthography and spelling mistakes after which student then goes on to individually memorize that portion of the Qur'an he had chosen.

After the completion of the school, at certain level the Almajiri now becomes an independent "Gardi" and leaves the Tsangaya to start his own Tsangaya elsewhere, mostly in a distant location to avoid competing with his guru and to spread the tradition as well. In the Tsangaya it is a cycle of younger Almajirai replacing grown up gardawa who either graduate by completing the memorizing the holy Qur'an or giving up to join trade or engage in full time farming. However, unlike the Pondok the Gardi only return only on annual homage or as the situation may warrant to pay meet the

17 Shehu, "No TiIMPROVING QUR'ANIC (TSANGAYA) EDUCATION IN NIGERIA Trends, Issues, Challenges and the Way Forward tle." 
Guru as a life time routine. Furthermore, Tsangaya has no provision for older people to learn as permanent residents. One can only visit on daily basis as a family or an elderly man to consult the Mallam through a specific textbook suitable to one state of knowledge. (Hashim R. 2011) in the case of the Tsangaya, most are located in the northern states of Nigeria.

In contrast, while the Pondok is stable with a fixed location, the Tsangaya is rather fluid and flexible and can relocate as many times as possible across the year and between regions to another town or city based on the availability of sustaining an income for the Mallam. In contrast to the Tsangaya, most Pondok establishments have fixed locations and people go there to join as both young and old. Most Pondoks are located in the northern-most region of the Peninsula, especially in the states of Kedah, Kelantan, Perlis, and Terengganu. These states were once under the control of the Siamese Empire. (Hashim R. 2011).

\section{Potentials of Pondok and Tsangaya environments in old age spiritual wellbeing.}

In relation to old age, the major areas of differences between the Pondok and the Tsangaya is the ability of the Pondok to accommodate old age and the elderly in its function. This makes the Pondok unique an outstanding and a relevant Islamic value of eldercare that has the glaring potentials to face the challenges of aging. Apart from serving as a Traditional Islamic Educational Institution, even in modern periods within Malaysia, the Pondok has been developed to be a place for elderlies to seek continual religious education as well as a new settlement that suits their needs within a sociable and supportive environment after retirement for spiritual wellbeing. (ibrahim 2012) In contrast the Tsangaya can be consulted by arrangement for special prayers and learning by elderly either on daily basis usually in the morning or afternoon or at the weekends to recite the Quran or other books offered by the guru in Fiqh Hadith and Arabic language in addition to other consultations.

The Spiritual well-being of the retired elderly is the main goal of the Pondoks. This is done if possible in harmony to cultural-values, choice of the Pondok environment and location of where the elderly live. As much as possible a harmonious relationship with family members is made to remain. Salma and Fuziah revealed that, those interested in living in Pondoks characteristically exhibit strong values of spirituality and community orientation and as much as possible Pondok communities 
also comply by enabling them to live in harmony. This because, at the point of entry into the Pondok, the burden of care no longer rests on immediate family; instead, the Pondok community takes over care functions.

While the Pondoks are stable on fixed and even permanent locations, the Tsangaya is fluid and mobile in most cases, with very few in fixed locations. Both systems face Problems associated with modernization and the rise of other brands of Islamic teaching methods. Aspects of the Pondoks can be adapted to accommodate the need of elderly people especially in communities across the northeast where similarities in religion exists with Malaysian society.

Unlike the Tsangaya, the Pondok is an environment that suits the needs of the elderly people. They may either build a small classroom or "musolla" or Mosque in a plot of land owned by them or pledged by others on a basis of wakaf (endowment). These places are also used as venues to teach Islam apart from the normal use as a place of worship. When the classes or mosque could not accommodate the demand, the operators or the teachers invite the Muslim within the community to pledge their lands or properties for wakaf either for the benefit of the public or for a specific purpose. (Rosnani 2004). In contrast, very few cities and towns accommodate the Almajiri in Nigeria. In most places within the south and western parts of Nigeria, the Almajiri is seen and treated as a social misfit and accorded harmful and discriminatory treatments.

A number of studies that have explored living arrangement of older persons, indicted the importance of the Pondok living arrangement on the elderly wellbeing. As such, there exist a high tendency among the Malay elderly to choose the Pondok as a choice and style of living in old age. Currently, in most instances, basic amenities like health care, water and electricity are available within the Pondoks. Such incentives make the pursuit of spirituality and religious satisfaction with like-minded people, a fulfilling experience and opportunity to passed on into final moments in devotion.

A qualitative inquiry conducted on Pondok dwellings as alternative living arrangements, indicated five reasons why older persons opt to choose the Pondok as their residence are to be consistent in performing their worship, ease and ability to join the congregation, "Jemaah" in the mosque, ability to socialize and learn together with religious peers, performance of good deeds for the afterlife and capably to further enhance religious knowledge (Zainab 2012). 
In general, there are two types of Pondok retirement villages. the Malay kampong, found in rural areas throughout the peninsula and the eastern States and the Pondok spiritual community which occurs in the northern States of Kedah, Perak, Kelantan and Trengganu. The first type is "Donor-funded villages are funded by way of charitable and/or government contributions". Under this type the residents also donate on entering the village, such donation being non-refundable. While the second type is "Resident-funded villages", are villages whose total capital expenditure is obtained from residents by way of ingoing payments for the "purchase" of self-care units or assisted apartments occupied, with such ingoing payments being refundable in full or impart in accordance with the resident's contract at the commencement of stay. (Sufian 2013)

From the onset of the establishment of the Islamic education in Nigeria, the Jihadist emphasis on filial duty emphasized spirituality among the elderly through "Sufism". This is practiced in brotherhood membership of either the "Qadriyya" or "Tijjaniya" sects. In relation to eldercare, emphasis was on filial obligations within households as a duty of children. The teachings of Dan Fodio in relation to elderly were based on Parent-Child Obligations as important aspects of the post jihad social order in Hausa land. In a book titled "Fawaid Mujmilah fi-ma jaa fil-birr wal Sillah" the duty of a child to obey his parents were spelt out. The basis of the teachings was derived from a number of traditions relating Allah s injunctions and teachings of the Sunnah on filial obligation. For example, the affection for one's mother should exceed that given to the father threefold, since the mother bears the burden of conception, the burden of childbirth and the burden of nursing.

According to Muhammad Bello,

"Five duties......... devolve on a responsible person in respect of his parents. First, that he should not be arrogant towards them . . . ; two, that he should avoid rebuking them even when they confront him with what he dislikes; three, that be should address them in a pleasing, respectful manner . . . as a humble servant addresses his auspicious master; four, that he should show great affection to them for instance, he should neither raise his voice in their presence nor walk in front of them and he should do what they want, without of course disobeying the law, showing them love, compassion, reverence, and serving them in an excellent manners; five, that he should always pray for Allah s mercy on them; if they are Muslims, and offer sadaqa on their behalf after they are dead".

(Sulaiman I. 1986, Van Beek 1988). 
Therefore, there was heavy emphasis and reliance of eldercare within the home environment as against institutional approach.

Challenges and critiques: Both Tsangaya and the Pondok faces a number of challenges. The challenges facing the Tsangaya or Almajiri system in relation to the individual student (Almajiri), teachers (Mallams), and the larger society (Ummah) are numerous and overwhelming on the current structure of the Almajiri system. The Almajiri syndrome is a phenomenon seen by many as highly detrimental to the society in Nigeria (Abdulrahman, 2007). With reference to Northern Nigeria, the menaced of the Tsangaya system manifests in begging and its consequences. As noted by Ammani $^{18}$

"The population of beggars on our streets is growing exponentially. Many social commentators have attributed this astronomical growth in street begging to poverty... in the North... to most non-Muslim minds, Islam is not only associated with begging but appears to encourage it".

Much as this is a clear misconception, the fact remains that street begging prevails because :

"we Muslims, particularly some of our leading malams, provided it with a fertile ground to thrive... In the name of almajiranci, some malams take children away from their parents into major towns and cities and transformed them into marabata (professional beggars) ... these people (children) are made to beg for money on the streets" ${ }^{19} \cdot(\mathrm{pp} 1-2)$

Consequently, the general perception of the Tsangaya system is that of basis for sustaining a culture of poverty in the region. This is because, as individuals, the Almajirai (students) are highly exploited in the Tsangaya system following the greed and materialist inclination of some malams (traditional ulama) who have departed from the traditional life of dedication to the calling. This over-ambitiousness coupled with negligence of parents and the absence of sanctions from the authorities, makes the Tsangaya system impossible to successfully operate as a system of education. In most cases the malams engages the almajirai (students) more in begging than the primary

18 Ammani A. A., "'Street begging: Exposing the bankruptcy of blatant paying of lip service.' No Title," dalam Proceedings Of SEVENTH INTERNATIONAL CONFERENCE THE TAWHIDI EPISTEMOLOGY: ZAKAT AND WAQF ECONOMY, 2010.

19 Ammani A. A.; JR Lewis dan IB Tollefsen, The Oxford handbook of new religious movements, 2016. 
purpose of Qur'anic education, there is high prevalence of child labor, and exposure to various dimensions of social pathologies rather than abiding the Islamic teaching.

Abdul Qadir ${ }^{20}$ added that , "The Almajiri system of education as practiced today in the northern Nigeria is a completely bastardized system compared to the form and conditions under which the system was operating and its output during the precolonial period. The system has been forced, especially with the coming of the British, to its present pitiful state. During the pre-colonial era, begging was never involved and certainly the pupils were not reduced to doing menial jobs before they could eat"

Psychologically, it instills in the children a sense of inferiority, dependency, rejection, and all sorts of negative psychological dispositions. In the social sphere their limitless movements and interactions exposes them, and in many cases, gets them induced a number of social vices. They easily come across various kinds of dangerous juvenile and adolescent peers. Indeed, they come across/witness all sorts of people and experiences in the society - the good, the bad and the ugly. As juveniles, they can hardly discern the right from the wrong, especially if they see people that are rather respectful and responsible committing them. They are at the mercy of enormous indiscriminate and arbitrary agents of socialization in the society that undoubtedly wage a lot of influence on them more than their Tsangaya. ${ }^{21}$ This is another area of sharp contrast between the Tsangaya and Pondok system as system that originates from Islamic Arabic education system, this is based on the fact that the Pondoks are an integral part of the Muslim community. ${ }^{22}$

like many other Islamic schools across the world, Pondoks have been suspected of imparting jihadist ideas or training militants. This has increased the desire to reform them, which would also improve the social conditions of the community. Studies on the Tsangaya Almajiri system also indicates that it is partly, responsible for high number of child-beggars (Almajirai) on Nigerian streets as well as child poverty. The blame has been on the Northern Nigerian leaders as well as lapses in Islamic

${ }^{20}$ AbdulQadir I. A., "“The Al-Majiri System of Education in Nigeria Today.”

21 EO Akubor, "POVERTY AND TERRORISM IN NORTHERN NIGERIA: REFLECTIONS AND NOTES ON THE MANIPULATION OF THE ALMAJIRAI SYSTEM AND ITS," Modern Africa: Politics, History and Society, 2016.

${ }^{22}$ TI Gomment dan OS Esomchi, "Nigeria: Breeding Future Terrorists. A Study of Almajiri of Northern Nigeria and Islamist Militia.," Conflict Studies Quarterly, 2017. 
scholarship and politicians who have conspired persistently to constrain the progress of the region to a destiny of poverty.(Gomment \& Esomchi, 2017)

Findings by Shittu \& Olaofe (2015), revealed that, as the Almajiri (students) embarked on the journey for knowledge , 6 out of 10 are highly likely to have gone forever. Most end up losing their lives in street violence in cities like kano, death as victims of ritual killings, end up being kidnapped, suffer diseases and may die from hunger $^{23}$. The few that could survive the vagaries of Tsangaya living conditions are often exhausted on the streets and are likely to eventually drop out. Most of foot soldiers in the current insurgency within Nigeria and her neighbors are recruited from the al-Majiri . This is because they are easy to brainwash due lack of proper foundation in Islamic knowledge that they are expected to have obtained ${ }^{24}$. Instead of serving as a source for future Islamic scholars, the Tsangaya system wastes away the children by ending up as housekeepers, watchmen, conductors and criminals ${ }^{25}$.

Recently, the Sultan of Sokoto, Sa'ad Abubakar, said that street begging by children has no basis in Islam and challenged those engaging in the act to find other means of earning a living. Furthermore, "Almajiri system of begging is not representing Islam and must, therefore, be dissociate from Islam. "Islam encourages scholarship and entrepreneurship and frowns at laziness and idleness as exemplified by itinerant Almajiri"

Although there exists less documented criticism of the Pondok system, there were criticism led by the 'kaum muda' reformists for the constricted methods of teaching Islam in the Pondok. The reformists disagreed with the Pondok system of teaching the tenets of Islam through memorization and repetition because it "did not prepare the Muslim youths for socio-economic changes and new employment created by the British colonialists. The 'kaum muda' subsequently established reformist Islamic schools like 'Madrasah Al-Iqbal', which adopted a different approach to the study of

\footnotetext{
M. Sagir,

"'Almajiri

Tsangaya

Foundation.,'" http://almajiritsangayafoundation.gnbo.com.ng/Almajiri+Tsangaya+Foun dation, 2015.

${ }^{24}$ I and Juliana J. Goodluck, "Provision of Formal Education to Almajiris: The Role of Libraries,'" European Scientific Journal Vol.8, no. No.15, (2013): 97-108.; Gomment dan Esomchi, "Nigeria: Breeding Future Terrorists. A Study of Almajiri of Northern Nigeria and Islamist Militia."

${ }^{25}$ P. Christian, “'Nigeria's Almajiri Children Learning a Life of Poverty and Violence,'No Title," http://edition.cnn.com/2010/WORLD/africa/01/07/nigeria.children.radica lization/, 2015.
} 
Islam by including the study of secular subjects such as English and mathematics in the curriculum $^{26}$. The reformists version of westernized education system eventually brings the 'kaum muda' into conflict with the religious traditionalists called the 'kaum tua', or "old faction" who were made up of the official religious hierarchy, the traditional Malay elite and the rural religious teachers of the Pondok and Quranic schools

\section{CONCLUSION AND RECOMMENDATIONS}

In conclusion, both Pondok and Tsangaya as traditional educational approaches in the teaching of Islam are rooted in the history of Malaysia and Nigeria however the Pondok possessed an "age" over the Tsangaya with special reference to spirituality, later life experience and eldercare. As such, reviewing the status of the Tsangaya to reflect later life needs of Nigerian Muslims can go a long way in providing and avenue for spiritual fulfillment and well-being of elderly Nigerian Muslims. It is recommended that the Tsangaya be modelled along the Pondok by regulating the establishment of Tsangaya on fixed locations and the provision of social amenities relevant to the needs of the elderly.

The educational sector to commit more financial and human resources towards including the needs of the elderly in local adult educational arrangement so as to promote better aging in place initiatives. communities should be encouraged to promote local settlements similar to the Pondoks of Malaysia to be adapted to the needs of the elderly in a manner that suits the local culture..

\section{REFERENCES}

Abdullah, A. "The Influence of Ethnic Values on Managerial Practices in Malaysia." Malaysian Management Review, 1993, 3-18.

AbdulQadir I. A. "“The Al-Majiri System of Education in Nigeria Today." ,"www.gamji.com/index.php/SJPAS/article/view/637, 2015.

Abidin, MZHBZ, PB Maidin, dan MYBY Salleh. "Survival of the Pondok Learning Institution in Malaysia." International Journal of, 2017.

Akubor, EO. "POVERTY AND TERRORISM IN NORTHERN NIGERIA: REFLECTIONS AND NOTES ON THE MANIPULATION OF THE ALMAJIRAI SYSTEM AND ITS." Modern Africa: Politics, History and Society, 2016.

Ammani A. A. "'Street begging: Exposing the bankruptcy of blatant paying of lip service.' No Title." Dalam Proceedings Of SEVENTH INTERNATIONAL

${ }^{26}$ A Othman, S Hussien, dan ... IS Ahmad, "Islamic integrated education system model in the Malay archipelago: Implications for educational leadership," Intellectual ..., 2017. 
CONFERENCE THE TAWHIDI EPISTEMOLOGY: ZAKAT AND WAQF ECONOMY, 2010.

Areff, NA, dan N Lyndon. "Meanings of old age to the elderly in pondok living arrangement in Malaysia." Mediterranean Journal of Social Sciences, 2015.

Awang, H.S. "Current Program Implementation and Evaluation." Dalam Proceedings of the National Seminar on Challenges of Senior Citizens Towards Vision 2020, 1992.

Beek, Van. "Intensive slave raiding in the colonial interstice: Hamman Yaji and the Mandara Mountains (North Cameroon and North-eastern Nigeria)No Title." The Journal of African History 53, no. 03 (2012): 301-23.

Christian, P. "'Nigeria's Almajiri Children Learning a Life of Poverty and Violence,'No Title."

http:/ / edition.cnn.com/2010/WORLD/africa/01/07/nigeria.children.radica lization/, 2015.

Fafunwa, A. Babs. History of Education in Nigeria. 2004 ed. ibadan: defemson, 2004.

Gomment, TI, dan OS Esomchi. "Nigeria: Breeding Future Terrorists. A Study of Almajiri of Northern Nigeria and Islamist Militia." Conflict Studies Quarterly, 2017.

Goodluck, I and Juliana J. "Provision of Formal Education to Almajiris: The Role of Libraries,.'" European Scientific Journal Vol.8, no. No.15, (2013): 97-108.

Ibraheem A.K. "The Jihad and the Consolidation of Sudanic Intellectual Tradition." Dalam International Conference on the Bicentenary of the Sokoto Caliphate 1804-2004, online version, 2004.

Lewis, JR, dan IB Tollefsen. The Oxford handbook of new religious movements, 2016.

Mydin, MM, dan NS Ahmad. "The system of Islamic studies at madrasah (sekolah pondok)," 2014.

Othman, A, S Hussien, dan ... IS Ahmad. "Islamic integrated education system model in the Malay archipelago: Implications for educational leadership." Intellectual ..., 2017.

Rahim, A, S Idha, MA Yakob, M Mansor, dan S Khurshiah. "Talaqqi Method in Teaching and Learning Islamic Education at Pondok Institutions," 2016.

Sagir, M. "'Almajiri Tsangaya $\quad$ Foundation." http:/ /almajiritsangayafoundation.gnbo.com.ng/Almajiri+Tsangaya+Foun dation, 2015.

Samuel, M, MY Tee, dan LP Symaco. "The Educational Landscape of Malaysia." Education in Malaysia, 2017.

Shehu, Salisu. "No TiIMPROVING QUR'ANIC (TSANGAYA) EDUCATION IN NIGERIA Trends, Issues, Challenges and the Way Forward tle." Dalam Tsangaya System of Education, Organized by the Borno State Agency for Mass Education, Maiduguri, na, 2006.

Yusoff, Zurita Mohd, Siti Fatimah Salleh, Hasanulddin Mohd, Jamalluddin Hashim, Mohd Zaidi, Md Zabri, Ramlah Binti, dkk. "Contemporary Fiqh Thoughts of Shaykh Abdul Malik bin Abdullah (1650-1736AD) in Kitab al-Kifayah." International Journal of Academic Research in Business and Social Sciences 7, no. 4 (2017): 2222-6990. https://doi.org/10.6007/IJARBSS/v7-i4/2774. 